International Journal of Social Science and Economic Research

ISSN: 2455-8834

Volume:06, Issue:02 "February 2021"

\title{
PERCEPTIONS OF PREPARING FOR RETIREMENT
}

\author{
Sumalee Pumpinyo ${ }^{1}$ and Saowaluck Koojaroenprasit ${ }^{2}$ \\ ${ }^{1}$ Assistant Professor, Faculty of Economics, Kasetsart University,Bangkok 10900, Thailand \\ ${ }^{2}$ Associate Professor, Faculty of Economics, Kasetsart University, Bangkok 10900, Thailand \\ DOI: 10.46609/IJSSER.2021.v06i02.022 URL: https://doi.org/10.46609/IJSSER.2021.v06i02.022
}

\begin{abstract}
Structural changes that occur as a result of an ageing society are an important issue that every country in the world must address. Perceptions of preparing for retirement are important because they will help people prepare for better life after retirement. In this study, we intendedto understand the perceptions of individuals towards preparing for retirement from multiple aspect such as health, mental wellbeing and economics, among others. The study involved interviews of 400 people aged between 50-60 years old using a questionnaire survey. A weighted average index was applied to measure perceptions of the respondents and test mean differences between occupations. The results show the respondents were concerned about health, mental wellbeing and economic aspects. The respondents who work in civil service have good perceptions and are better prepared than people in other occupations, while private company employee have the weakest perceptions.
\end{abstract}

Keywords: Retirement, Aging.

\section{Introduction}

Population ageing is already a challenge. There is concern that individuals are not preparing adequately for retirement and the ageing populations in many developed countries further exacerbate the problem. This is now recognized as a global issue of increasing importance as there is a rapid growth in the number of older people worldwide, which has created an unprecedented global demographic revolution. Developing countries currently have less of a problem in terms of ageing populations. However, it is estimated that by 2050 , more than $80 \%$ of the worldwide population over the age of 60 years will reside in developing countries (United Nations, 2015). Structural changes of an ageing society are important issues that everycountry in the world must face. Many countries have ageing societies. In 1990, the share of people older than 60 years was around $9.2 \%$ and this increased to $11.7 \%$ in 2013. It is estimatedthat this number will grow to $21.1 \%$ in 2050 . This will be especially true in China, Taiwan, Japan, Germany and Hong Kong. Another estimate is that the world's elderly will increase by $60 \%$ in fifteen years. In 2030 , total number of elderly people in the world will be around 1,000 million persons. It will 
International Journal of Social Science and Economic Research

ISSN: 2455-8834

Volume:06, Issue:02 "February 2021"

increase to 1,600 million persons in 2050, as shown in Table 1 (UnitedNations, 2015).

Table 1 Total number of adults older than 65 years in 2016, 2030 and 2050

\begin{tabular}{|l|l|l|l|l|l|l|l|l|l|}
\hline \multirow{2}{*}{ Year } & \multicolumn{2}{l|}{ Total Population (persons) } & \multicolumn{2}{l|}{$\begin{array}{l}\text { Population over 65 years } \\
\text { (persons) }\end{array}$} & \multicolumn{2}{l}{$\begin{array}{l}\text { Population over 65 years } \\
(\%)\end{array}$} \\
\cline { 2 - 10 } & Total & male & female & male & female & total & male & female \\
& & & & & & & & \\
\hline 2016 & $7,253.3$ & $3,652.0$ & $3,601.3$ & 617.1 & 274.9 & 342.2 & 8.5 & 7.5 & 9.5 \\
\hline 2030 & $8,315.8$ & $4,176.7$ & $4,139.1$ & 998.7 & 445.2 & 553.4 & 12.0 & 10.7 & 13.4 \\
\hline 2050 & $9,376.4$ & $4,681.7$ & $4,694.7$ & $1,565.8$ & 698.5 & 867.3 & 16.7 & 14.6 & 18.5 \\
\hline
\end{tabular}

Source: U.S. Census Bureau, 2013. International Database

The concept of retirement leaves different people with various ideas. While some persons view it positively and await it with happiness, some have negative perceptions about retirement. They associate this period of their life with boredom, economic hardship and death. As a result some individuals feel a sense of isolation and loss of prestige. When people becomeelderly and retire, they can be categorize in three groups. The first group can do outside activities, while the second group may stay at home and are reluctant to go anywhere. The lastgroup is bedridden.

An ageing population is one in which there is an increase in the proportion of people aged 60 years and older. They are referred to as the elderly or as senior citizens. The majority of peopleare not prepared for retirement and they do not know what they will do when their time comes. Preparing for retirement will bring benefits to them, but if they do not prepared for retirement, they will experience stress and anxiety. Retirement planners accumulate more wealth than nonplanners through savings, investments, and probably their selling homes to finance retirement, among other strategies (Lusardi and Mitchell, 2007). Most research about preparing for retirement focuses on its financial aspects, but in the current study, it was intended to understand the perceptions of individuals towards preparing for retirement in other aspect suchas their health and mental wellbeing, among others, for happier senior years.

\section{Literature Review}

Retirement is an essential end, one that everyone must experience (Obimba, 2005 cited in Sara Saeed and Aamir Sarwar 2016). In fact, retirement is an era for individuals to rest and decelerate into a calm life and prepare themselves for old age. Moreover, retirement can be perceived as a period of freedom when retired individuals can pursue long-postponed goals. There is season for everything. There is a time to retire and a time to rest. It is a conversion from an active work life to world of leisure (Denga, 2010 cited in Sara Saeed and Aamir Sarwar2016). Perera S. et al. 2012 


\section{International Journal of Social Science and Economic Research}

ISSN: $2455-8834$

Volume:06, Issue:02 "February 2021"

studied perceptions of the members of a retirement organization. They examined the retirement of medical professionals. Focus groups and in-depth interviews were used to generate the study data. They found medical professionals demand a clear contribution in terms of the design of the retirement process from healthcare institutions. Theywant recognition of their role and expertise and a collaborative approach to designing a retirement process. According to Badmus et al. (2016), interviews in Nigeria among 385 people aged 50 years and older, the respondents' perceptions of old age was as a period of economic insecurity and loneliness. Shailesh T. et al. (2019) studied perceptions of individuals towards retirement planning. Their results reveal the majority of respondents invest as part of their retirement planning. In China, majority of people do not prepare for retirement with financial literacy, especially woman and people of less educated groups (Niua, G. et al. 2020). Sara Saeed and Aamir Sarwar (2016) studied retirement issues and planning by academic staff of a public sector university in Pakistan. A questionnaire was developed and used to collect primary data from a sample of 254 people using convenience sampling. The study found that the majority of the respondents prefer to invest in gold, precious metals, and in real estate as part of their planning for life after retirement. Santos A.L.P.d et al. (2016) revealed that the perception of the athletes about the support system at the end of one's sports career is mostly negative. The results revealed that the majority of the athletes believed that the prospects for high-performance athletes after retirement are few and express concern about what will happenafter their sports career ends. Michelle Reyers (2018) used data from a national survey of South Africans to determine how confident workers are about their future retirement income and whether behavioral characteristics play a role in their perception of retirement readiness. The study showed that a perspective of good financial behavior and selfassessed financial knowledge are positively related to retirement confidence of the respondent.

\section{Methodology}

The current study measured perceptions of the elderly toward preparation for retirement at agesbetween 5060 years old. Four-hundred people were interviewed using a questionnaire surveyexamining six aspects: health, mental wellbeing, economic considerations, adaptability after retirement, self-esteem, and knowledge of welfare. Differences between occupational groups were tested through ANOVA. Internal consistency was estimated using Cronbach's Alpha. A Cronbach's Alpha of 0.958 was obtained, indicating a highly reliable instrument.

Questionnaire responses used a five-point Likert scale to assess respondents' opinions about their perceptions on retirement planning. Then, a weighted average index (WAI) was applied to the results. The WAI was computed using following equation:

$$
I=\frac{\sum s_{i} f_{i}}{N}
$$


where, $\mathrm{I}=\mathrm{WAI}$, such that $0 \leq I \leq 1$, si denotes the scale value at $\mathrm{i}^{\text {th }}$ priority ranging from very poor, poor, moderate, high to very high, $f i$ denotes frequency of $\mathrm{i}^{\text {th }}$ priority and $\mathrm{N}$ is equal to the total number of observations, i.e., $\sum f_{i}$. The WAI was used to transform the opinions of respondents from a nominal scale (very poor-very high) into numeric scores. The scores were classified into five levels such that $0-0.20=$ very poor, $0.21-0.40=$ poor, $0.41-0.60=$ moderate, $0.61-0.80=$ high, and $0.81-1=$ very high $($ Md Abdul, 1993).

\section{Results of the study}

From the study, most of the respondents were female, aged 50-55 years, married, and university graduates. Typically, they are private company employees or self-employed with monthly income greater than 90,000 baht. The majority of the respondents had two children and were responsible for the care of two people. Most of respondents did not have debt burden and they did have health and life insurance. They invested in mutual funds, securities, gold, and real estate in the form of land and houses that they rented. The majority of the sample did not plan to do business after retirement.

Table 2 Basic data $(n=400)$

\begin{tabular}{|c|c|c|c|}
\hline \multirow{2}{*}{\multicolumn{4}{|c|}{$\begin{array}{l}\text { Data } \\
\text { 1. Gender }\end{array}$}} \\
\hline & & & \\
\hline \multicolumn{2}{|l|}{ Male } & 131 & 32.75 \\
\hline & & 269 & 67.25 \\
\hline \multicolumn{4}{|l|}{ 2. Age (years) } \\
\hline \multicolumn{2}{|l|}{$50-55$} & 224 & 56 \\
\hline \multicolumn{2}{|l|}{$56-60$} & 176 & 44 \\
\hline \multicolumn{4}{|l|}{ 3. Education } \\
\hline Senior secondary & 24 & \multicolumn{2}{|r|}{6} \\
\hline Bachelor's degree & 188 & \multicolumn{2}{|r|}{47} \\
\hline $\begin{array}{l}\text { Master's degree and over } \\
4 \text { Status }\end{array}$ & 188 & \multicolumn{2}{|r|}{47} \\
\hline Single & 107 & & 26.75 \\
\hline Married & 254 & \multicolumn{2}{|r|}{63.5} \\
\hline \multicolumn{2}{|l|}{ 5. Occupation } & \multicolumn{2}{|r|}{9.75} \\
\hline State enterprise employee & 48 & & 12 \\
\hline Private company employee & 127 & \multicolumn{2}{|r|}{31.75} \\
\hline Personal business/self-employed & 117 & \multicolumn{2}{|r|}{29.25} \\
\hline Civil service & 108 & \multirow{2}{*}{\multicolumn{2}{|c|}{27}} \\
\hline \multicolumn{2}{|l|}{$\begin{array}{l}\text { 6. Income of age } 50-60 \text { years } \\
\text { (baht per month) }\end{array}$} & & \\
\hline Less than 30,000 baht & 51 & & 12.75 \\
\hline
\end{tabular}


$30,001-50,000$

$50,001-70,000$

$70,001-90,000$

Over 90,000

7. Number of Children

0

1

2

3

More than 3

8.Burden of raising a family

0

1-2

3-5

More than 5

9. Housing owner

Own

Family

Hire

Debt

Other

10. In Debt

No Debt

Have Debt

11. Health Insurance

No Health Insurance

Have Health Insurance

12. Life Insurance

No Life Insurance

Have Life Insurance

13.Type of Investment in securities

Gold

Mutual Funds

Securities

Real Estate for Rent

14.Type of Real Estate for Rent Land

Condominium

House

Other

15.Plan for Business after

Retirement

Intend to do Business/Personal
21

22.25

9.75

34.25

34.5

19.25

35.5

9.25

1.5

30.8

47.5

21.25

0.75

74.25

22.75

1.25

.5

1.25

55

45

40.50

59.50

16.60

83.50

18

43

29

10

32

27

29

12 
Business

No

\section{Perceptions on preparing for retirement}

Perception on preparing for retirement can be categorized in six aspects: health, mental wellbeing, economic considerations, ability to adapt after retirement, self-esteem and knowledge of welfare. For health considerations, the respondents realized that preparing for good health is most important, and they could accept the mental wellbeing challenges of retirement. The study showed that the respondents more heavily emphasized mental wellbeing and economic considerations than other aspects. They had less knowledge of welfare considerations. Economically, they realized saving and financial planning is important. For adaptation after retirement, they perceived less challenge of work. They thought that they willstill value family.

Overall, the respondents have very high perceptions of all aspects except self-esteem and knowledge on welfare. The highest perception and awareness is that they must have goodhealth and enough income after retirement, and the lowest perception is news about funds for welfare.

Table 3 Perceptions on preparation for retirement

\begin{tabular}{|l|l|}
\hline & WAI \\
\hline Perceptions on preparing for retirement & \\
\hline 1. Degenerath aspect & 0.8445 \\
2. Preparing of knowledge of nutrition for health & 0.7495 \\
3. Daily exercise for good health after retirement & 0.7460 \\
4. Study about the elderly disease & 0.7475 \\
5. Good health before retirement is necessary & 0.9075 \\
\hline Total score on health aspect & $\mathbf{0 . 7 9 9 0}$ \\
\hline 2. Mental wellbeing aspect & \\
\hline 1. Perception of retirement & 0.8725 \\
2. Leisure activities helpful after retirement & 0.8595 \\
3. Adaptive to change & 0.8255 \\
\hline
\end{tabular}




\section{Perceptions on preparing for retirement}

4. After retirement, they will have time for activities and rest

5. Meditation for mental wellbeing

Total score on mental wellbeing aspect

$\mathbf{0 . 8 5 9 7}$

\section{Economic Aspect}

1. Saving is benefit to have sufficient income after retirement

2. Supplementary career important for retirement

0.9005

0.7760

3. Knowledge of financial planning is important

0.8555

4. Reserve money for home repairs

0.8365

5. Reserve money for medical treatment

Total score on economic aspect

0.8508

4. Ability to adapt after retirement

1. Adaptive life

2. Accept that they have left their work

3. Willing to pursue leisure activities and education

4. Successful in life after retirement

0.7770

5. After retirement still find challenging things to do

0.7470

Total score on ability to adapt after retirement

0.8049

\section{Self-esteem (appreciate oneself) aspect}

1. Work for social good

0.8260

2. Value family

0.8435

3. Socially active such as going to parties

0.7740

4. Transfer expert knowledge

0.7305

5. Good relationships and easily makes friends with other people

0.7890

Total score on self- esteem

0.7926

6. Knowledge on welfare aspect

1. Knowledge of provident funds, welfare funds

0.7585 
2. Benefits of funds after retirement

0.7595

3. Follow the news of funds for welfare of the elderly

0.7190

Perceptions on preparing for retirement

Total score on knowledge of welfare aspect

WAI

Total score on preparing for retirement

0.7457

0.8088

Weighted Average Index (WAI): $0-0.20=$ very poor; $0.21-0.40=$ poor; $0.41-0.60=$ moderate; $0.61-0.80=$ high; $0.81-1=$ very high

\section{Hypothesis test of mean differences among occupations}

The respondents' occupations were categorize in four groups, civil service, self-employment, private company employee and state enterprise employee. The study showed that civil servants and self-employ people had nearly the same perception in all aspects, while private company employee perceptions were lower than other groups. However, all groups hadhigh perceptions of mental wellbeing and economic aspects and less perception of welfare. On health aspects, state enterprise employees had better perceptions than other groups, while civil servants had the best perceptions on mental wellbeing. Civil servants perceive that after retirement they will have time for leisure activities. In the economic, self-esteem and welfare aspects, civil servants also the highest perceptions, while state enterprise employees were a little lower. Private employee lower perceptions in every aspect except knowledge of welfare, where the self-employed had the lowest (Table 4). 
Table 4 Perception of preparing for retirement separated by occupation

\begin{tabular}{|c|c|c|c|c|}
\hline \multirow[b]{2}{*}{ Perception for preparing retirement } & \multicolumn{4}{|l|}{ Occupation } \\
\hline & \begin{tabular}{|l|}
$\mathbf{a}$ \\
Civil service \\
$(\mathrm{N}=\mathbf{1 0 8})$ \\
WAI
\end{tabular} & $\begin{array}{l}\begin{array}{l}\text { b } \\
\text { Self- } \\
\text { employed }\end{array} \\
(\mathbf{N}=117) \\
\text { WAI }\end{array}$ & $\begin{array}{l}\text { c } \\
\text { Private } \\
\text { company } \\
\text { employee } \\
(\mathbf{N}=127) \\
\text { WAI }\end{array}$ & $\begin{array}{l}\text { d } \\
\text { State } \\
\text { enterprise } \\
\text { mployee } \\
(\mathbf{N}=48) \\
\text { WAI }\end{array}$ \\
\hline \multicolumn{5}{|l|}{ 1. Health aspect } \\
\hline 1. Degeneration of one's body $* *$ & $0.8630^{\mathrm{ab}}$ & $0.8410^{\text {ba }}$ & $0.8157^{\mathrm{cb}}$ & $0.8875^{\mathrm{da}}$ \\
\hline 2. Preparing of knowledge of nutrition for health $* * *$ & $0.7907^{\mathrm{ad}}$ & $0.7316^{\text {ba }}$ & 0.6866 & $0.7833^{\mathrm{dab}}$ \\
\hline 3. Daily exercise for good health after retirement & $0.7296^{\text {abcd }}$ & $0.7333^{\mathrm{abcd}}$ & $0.6709^{\mathrm{abcd}}$ & $0.7458^{\mathrm{abcd}}$ \\
\hline 4. Study about diseases of the elderly $* * *$ & $0.7796^{\mathrm{ad}}$ & $0.7145^{\mathrm{bc}}$ & $0.6803^{\mathrm{cb}}$ & $0.7750^{\mathrm{da}}$ \\
\hline 5. Good health before retirement is necessary & $0.9222^{\mathrm{abd}}$ & $0.9094^{\text {bacd }}$ & $0.8882^{\mathrm{cbd}}$ & $0.9208^{\mathrm{dabc}}$ \\
\hline Total score on health aspect & $\mathbf{0 . 8 1 7 0}$ & $\mathbf{0 . 7 8 6 0}$ & $\mathbf{0 . 7 4 8 3}$ & 0.8225 \\
\hline $\begin{array}{l}\text { 2. Mental wellbeing aspect } \\
\text { 1. Perceptions of retirement } * * * \\
\text { 2. Leisure activities helpful after retirement } * *\end{array}$ & $\begin{array}{c}0.9093^{\mathrm{ad}} \\
0.8870^{\mathrm{abd}}\end{array}$ & $\begin{array}{l}0.8786^{\mathrm{bd}} \\
0.8530^{\mathrm{bad}}\end{array}$ & $\begin{array}{l}0.8252 \\
0.8299\end{array}$ & $\begin{array}{l}0.8917^{\mathrm{dab}} \\
0.8750^{\mathrm{dab}}\end{array}$ \\
\hline & \multicolumn{4}{|l|}{ Occupation } \\
\hline
\end{tabular}




\begin{tabular}{|c|c|c|c|c|}
\hline Perception for preparing retirement & $\begin{array}{l}\text { a } \\
\text { Civil service } \\
(\mathrm{N}=108) \\
\text { WAI }\end{array}$ & $\begin{array}{l}\begin{array}{l}\text { b } \\
\text { Self- } \\
\text { employed }\end{array} \\
(\mathrm{N}=117) \\
\text { WAI }\end{array}$ & \begin{tabular}{|l} 
c \\
Private \\
company \\
employee \\
$(\mathrm{N}=127)$ \\
WAI
\end{tabular} & $\begin{array}{l}\text { d } \\
\text { State } \\
\text { enterprise } \\
\text { employee } \\
(\mathrm{N}=48) \\
\text { WAI }\end{array}$ \\
\hline $\begin{array}{l}\text { 3. Adaptive for change } * * \\
\text { 4. After retirement, will have time for activities and } \\
\text { rest } * * * \\
5 \text {. Meditation benefit for mental wellbeing * }\end{array}$ & $\begin{array}{l}0.8463^{\mathrm{abd}} \\
0.9111 \\
0.8759^{\mathrm{abd}}\end{array}$ & $\begin{array}{l}0.8239^{\text {bad }} \\
0.8547^{\text {bcd }} \\
0.8496^{\text {bacd }}\end{array}$ & $\begin{array}{l}0.7969 \\
0.8346^{\mathrm{cbd}} \\
0.8110^{\mathrm{cb}}\end{array}$ & $\begin{array}{l}0.8500^{\mathrm{dab}} \\
0.8708^{\mathrm{dbc}} \\
0.8583^{\mathrm{dab}}\end{array}$ \\
\hline Total score on mental wellbeing aspect & $\mathbf{0 . 8 8 8 6}$ & 0.8561 & 0.8265 & 0.8736 \\
\hline $\begin{array}{l}\text { 3. Economic aspect } \\
\text { 1. Saving is a benefit for sufficient income after } \\
\text { retirement } * * \\
\text { 2. A supplementary career is important for } \\
\text { retirement } \\
\text { 3. Knowledge for financial planning is important } \\
\text { 4. Have reserve money for home repairs ** } \\
\text { 5. Have reserve money for medical treatment }\end{array}$ & $\begin{array}{l}0.8778^{\mathrm{ab}} \\
0.7537^{\mathrm{abcd}} \\
0.8685^{\mathrm{abcd}} \\
0.8667^{\mathrm{ad}} \\
0.8778^{\mathrm{abcd}}\end{array}$ & $\begin{array}{l}0.8650^{\mathrm{ba}} \\
0.7761^{\mathrm{abcd}} \\
0.8410^{\mathrm{bac}} \\
0.8291^{\mathrm{bcd}} \\
0.8838^{\mathrm{abcd}}\end{array}$ & $\begin{array}{l}0.8299^{\mathrm{cd}} \\
0.7669^{\mathrm{abcd}} \\
0.8362^{\mathrm{cab}} \\
0.8094^{\mathrm{cbd}} \\
0.8724^{\mathrm{abcd}}\end{array}$ & $\begin{array}{l}0.8208^{\mathrm{dc}} \\
0.7500^{\mathrm{abcd}} \\
0.8875^{\mathrm{da}} \\
0.8417^{\mathrm{dabc}} \\
0.9083^{\mathrm{abcd}}\end{array}$ \\
\hline Total score on economic aspect & 0.8568 & 0.8496 & $\mathbf{0 . 8 3 4 6}$ & $\mathbf{0 . 8 5 2 8}$ \\
\hline $\begin{array}{l}\text { 4. Capability for adaptation after retirement } \\
\text { 1. Adaptive life } * * *\end{array}$ & $0.8574^{\mathrm{abd}}$ & $0.8274^{\mathrm{bad}}$ & 0.7764 & $0.8208^{\text {dab }}$ \\
\hline
\end{tabular}


International Journal of Social Science and Economic Research

ISSN: 2455-8834

Volume:06, Issue:02 "February 2021"

\begin{tabular}{|c|c|c|c|c|}
\hline \multirow[b]{2}{*}{ Perception for preparing retirement } & \multicolumn{4}{|l|}{\begin{tabular}{|l|} 
Occupation \\
\end{tabular}} \\
\hline & $\begin{array}{l}\text { a } \\
\text { Civil service } \\
(\mathrm{N}=108) \\
\text { WAI }\end{array}$ & $\begin{array}{l}\begin{array}{l}\text { b } \\
\text { Self- } \\
\text { employed }\end{array} \\
(\mathrm{N}=117) \\
\text { WAI }\end{array}$ & $\begin{array}{l}\text { c } \\
\text { Private } \\
\text { company } \\
\text { employee } \\
(\mathrm{N}=127) \\
\text { WAI }\end{array}$ & $\begin{array}{l}\text { d } \\
\text { State } \\
\text { enterprise } \\
\text { employee } \\
(\mathbf{N}=48) \\
\text { WAI }\end{array}$ \\
\hline 2. Accept that they have left their work ** & $0.8944^{\mathrm{ad}}$ & $0.8615^{\mathrm{bcd}}$ & $0.8346^{\mathrm{cb}}$ & $0.8833^{\mathrm{dab}}$ \\
\hline $\begin{array}{l}\text { 3. Willing to pursue leisure activities and education } \\
* *\end{array}$ & $0.8481^{\text {ad }}$ & $0.8103^{\mathrm{bcd}}$ & $0.7795^{\mathrm{cbd}}$ & $0.8250^{\text {dabc }}$ \\
\hline 4. Successful in life after retirement $* * *$ & $0.8019^{\mathrm{abd}}$ & $0.7966^{\text {ba }}$ & $0.6992^{\mathrm{cd}}$ & $0.7542^{\mathrm{dc}}$ \\
\hline 5. Will find challenging things to do in retirement** & 0.7833 & $0.7248^{\mathrm{bcd}}$ & $0.6913^{\mathrm{cbd}}$ & $0.6917^{\mathrm{dbc}}$ \\
\hline Total score on adaptation after retirement & $\mathbf{0 . 8 3 7 0}$ & 0.8041 & 0.7562 & $\mathbf{0 . 7 9 5 0}$ \\
\hline 5. Self-esteem (appreciate oneself) aspect & & & & \\
\hline 1. Work for social good $* *$ & $0.8537^{\mathrm{abd}}$ & $0.8393^{\text {bad }}$ & 0.7827 & $0.8292^{\text {dab }}$ \\
\hline 2. Value family $* *$ & $0.8759^{\text {ad }}$ & $0.8359^{\text {bcd }}$ & $0.8173^{\mathrm{cbd}}$ & $0.8500^{\mathrm{dabc}}$ \\
\hline 3. Socially active such as going to parties $*$ & $0.7870^{\mathrm{ab}}$ & $0.7744^{\text {bad }}$ & $0.7465^{\mathrm{cd}}$ & $0.7417^{\mathrm{dbc}}$ \\
\hline 4. Transfer expert knowledge $* *$ & 0.7648 & $0.6906^{\mathrm{bcd}}$ & $0.6677^{\mathrm{cbd}}$ & $0.7167^{\mathrm{dbc}}$ \\
\hline $\begin{array}{l}\text { 5. Good relationships and easily makes friends with } \\
\text { other people } * *\end{array}$ & $0.8148^{\mathrm{abd}}$ & $0.7880^{\text {bad }}$ & $0.7496^{\mathrm{cd}}$ & $0.7875^{\text {dabc }}$ \\
\hline Total score on self- esteem & 0.8193 & 0.7856 & 0.7528 & 0.7850 \\
\hline
\end{tabular}




\begin{tabular}{|c|c|c|c|c|}
\hline 6. Knowledge of welfare aspect & & & & \\
\hline \multirow[b]{2}{*}{ Perception for preparing retirement } & \multicolumn{4}{|l|}{ Occupation } \\
\hline & $\begin{array}{l}\text { a } \\
\text { Civil service } \\
(\mathrm{N}=108) \\
\text { WAI }\end{array}$ & 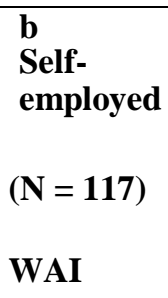 & \begin{tabular}{|l} 
c \\
Private \\
company \\
employee \\
$(\mathrm{N}=127)$ \\
WAI
\end{tabular} & $\begin{array}{l}\text { d } \\
\text { State } \\
\text { enterprise } \\
\text { employee } \\
(\mathbf{N}=\mathbf{4 8}) \\
\text { WAI }\end{array}$ \\
\hline 1. Knowledge of provident funds, welfare funds $* * *$ & 0.8333 & 0.6462 & $0.7386^{\mathrm{cd}}$ & $0.7833^{\mathrm{dc}}$ \\
\hline 2. Benefits of funds after retirement $* *$ & $0.7870^{\mathrm{acd}}$ & $0.6974^{\mathrm{bc}}$ & $0.7402^{\text {cab }}$ & $0.8083^{\mathrm{da}}$ \\
\hline $\begin{array}{l}\text { 3. Follow the news of funds for welfare of the } \\
\text { elderly } * *\end{array}$ & $0.7352^{\text {acd }}$ & $0.6496^{\mathrm{bc}}$ & $0.6882^{\text {cab }}$ & $0.7583^{\mathrm{da}}$ \\
\hline Total score on knowledge of welfare aspect & $\mathbf{0 . 7 8 5 2}$ & 0.6644 & $\mathbf{0 . 7 2 2 3}$ & $\mathbf{0 . 7 8 3 3}$ \\
\hline Total score on preparing for retirement & $\mathbf{0 . 8 3 4 0}$ & 0.7910 & 0.7735 & 0.8187 \\
\hline
\end{tabular}

Weighted Average Index (WAI): $0-0.20=$ very poor; $0.21-0.40=$ poor; $0.41-0.60=$ moderate; $0.61-0.80=$ high; $0.81-1=$ very high

* significance level at $0.10 * *$ significant level at 0.05

$* * *$ significance level at 0.01

Note: WAI values with superscript ' $a$ ' are significantly different from the ones with superscript ' $b$ '. WAI values with the same superscript, 'a' or ' $b$ ', are not significantly different. WAI values with superscript 'ab' are not significantly different from WAI values with either 'a' or ' $b$ '. 
International Journal of Social Science and Economic Research

ISSN: 2455-8834

Volume:06, Issue:02 "February 2021"

\section{Conclusions}

Overall, the respondents' perceptions about retirement after working for a long time is that retirement is a time for leisure activities. They are aware that they must exercise for good health, save for enough income to support themselves after retirement and have reserves for medical treatments. They are perceptive about how to manage health, mental wellbeing and economic matters. They were not sure about news related to funds for welfare and self-esteem. The current study supports the work of Michelle Reyers (2018) in that the respondents were concerned about the future adequacy of their funds in retirement, and as Badmus et al. (2016) found, that old age is a period of economic insecurity and loneliness. The civil servants were more confident in all aspect than those in other occupations because they have pension funds. Private company employee were less confident and worried more about their retirement than those in other occupations. The study suggests private company employees should plan to save money and invest to increase savings and ensure adequate income after retirement. Planners accumulate larger wealth than non-planners through saving, investment, and others means, as Lusardi and Mitchell (2007) found.

\section{References}

Badmus O. O. , Esan O. T , Badmus H. D , Arije O, 2016. Between Desire and Distaste: Perception of Persons near and above Retirement Age in South Western, Nigeria towards Old People's Homes Journal of Community Medicine and Primary Health Care. 28 (2) 19-25

Lusardi and Mitchell. 2007. Baby Boomer retirement security: The roles of planning, financial literacy, and housing wealth. Journal of Monetary Economics. Volume 54, Issue 1, Pages 205-224

Md Abdul, M. Q. 1993. Applied Statistics. Bangkok. Division of Human Settlements Development, Asian Institute of Technology.

Michelle Reyers. 2018. Perceptions of Retirement Adequacy: Evidence From South Africa. Journal of Financial Counseling and Planning, Volume 29, Number 2

Niua, G., Zhoub. Y., Ganc. H., 2020. Financial literacy and retirement preparation in China Pacific-Basin Finance Journal Volume 59

Perera, S., Matinez, M., Monreal-Bosch, P, 2012. Managing the Process of Retirement: The medical professional's Perceptions. Procedia - Social and Behavioral Sciences 82, 657 
International Journal of Social Science and Economic Research

ISSN: 2455-8834

Volume:06, Issue:02 "February 2021"

$-662$

Santos A.L.P.d, et al. 2016. Elite athletes' perception of retirement support systems.

International Journal of Physical Education, Sports and Health 2016; 3(1): 192-199

Sara Saeed and Aamir Sarwar, 2016, Perception about social and financial issues of life after retirement: A case study of academic staff of public sector universities in Lahore Pakistan, Cogent Business \& Management, 3:1, 1236432

Shailesh S. T., Jain S., Rameshwar, S., 2019. A study on perception of individuals towards retirement planning. International Journal of Applied Research 2017; 3(2): 154-157

United Nations. 2015. Department of Economic and Social Affairs, Population Division. World Population Prospects: The 2015 Revision.

U.S. Census Bureau. 2013. International Database.

https://www.census.gov/programs-surveys/international-programs/about/idb.html 